\title{
EVALUASI KEBUGARAN JASMANI MELALUI HARVARD STEP TESTPADA MAHASISWAPJKR TAHUN2016/2017 IKIP BUDI UTOMO
}

\author{
Havid Yusuf ${ }^{1}$ \\ Pendidikan Jasmani Kesehatan dan Rekreasi \\ Fakultas Pendidikan Ilmu Eksakta dan KeolahragaanIKIP Budi Utomo \\ Email: ${ }^{1}$ mu ball@yahoo.com
}

\begin{abstract}
ABSTRAK
Kebugaran jasmani pengertiannya yaitu kemampuan tubuh seseorang untuk melakukan pekerjaan sehari-hari tanpa menimbulkan kelelahan yang berarti. Salah satu tes kebugaran jasmani adalah Harvard Step Test. Evaluasi merupakan suatu usaha mengukur hasil dari suatu program dengan cara membandingkan dengan tujuan yg telah ditetapkan secara sistematis, dan bagaimana cara pencapaian tujuan tersebut. Instrumen tes yang dilakukan adalah naik turun bangku selama 5 menit dengan bantuan bangku Swedia dengan tinggi $45 \mathrm{~cm}$ dan stopwatch.Mahasiswa memeriksa denyut nadi (pulse) di menit pertama setelah naik turun bangku menggunakan stopwatch hingga menit ke tiga.Hasilnya, laki-laki (180) dan perempuan (12) mahasiswa IKIP Budi Utomo memiliki tingkat kebugaran yang baik dengan rata-rata 84.
\end{abstract}

Kata kunci: evaluasi, kebugaran jasmani, harvard step test

\begin{abstract}
Physical fitness, understanding that a person's body's ability to perform daily work without fatigue. One of the physical fitness test is a Harvard Step Test. Evaluation is an attempt to measure the results of a program by comparing with the goal that has been set out systematically, and how achievement of these objectives. Instrument test conducted are up and down the bench for 5 minutes with the help of the Swedish bench with a height of $45 \mathrm{~cm}$ and a stopwatch. Students checked the pulse rate (pulse) it in the first minute after going up and down the bench using a stopwatch up to three minutes. The results, the males (180) and females (12) students of IKIP Budi Utomo have a good fitness level with an average of 84 .
\end{abstract}

Keywords: evaluation, physical fitness, harvard step test 


\section{PENDAHULUAN}

Kebugaran jasmani merupakan tolak ukur seseorang dikatakan sehat atau tidak.Kebugaran dibutuhkan oleh setiap jenjang umur, mulai dari anak-anak sampai lanjut usia.Kebugaran jasmani pengertiannya yaitu kemampuan tubuh seseorang untuk melakukan pekerjaan seharihari tanpa menimbulkan kelelahan yang berarti (Perdana, 2008).Kesegaran jasmani pada hakekatnya berkenaan dengan kemampuan dan kesanggupanfisik seseorang untuk melaksanakan tugasnya sehari-hari secara efisien dan efektif dalamwaktu yang relatif lama tanpa menimbulkan kelelahan yang berarti dan masih memilikitenaga cadangan untuk melaksanakan aktivitas lainnya.

Jika seseorang ingin memiliki kondisi badan bugar, beberapa unsur-unsur kebugaran jasmani berikut dapat dijadikan sebagai pedoman, yaitu: 1) daya tahan kardiorespirasi (endurance), 2) daya tahan otot, 3) kekuatan otot (strength), 4) kelentukan (flexibility), 5) komposisi tubuh, 6) kecepatan (speed), 7) kecepatan reaksi (speed reaction), 8) daya ledak (power), 9) kelincahan (agility), 10) keseimbangan (balance), 11) ketepatan (accuracy), 12) koordinasi (coordination) (Remagari, 2010). Unsur-unsur kebugaran jasmani dapat diketahui melalui beberapa instrumen tes/prosedur pelaksanaan tes yang berguna bagi seseorang untuk mengetahui sejauh mana tingkat kebugaran jasmaninya.Salah satu tes kebugaran jasmani adalah Harvard Step Test.

Segala kegiatan manusia selalu memerlukan dukungan fisik.Kemampuan fisik merupakan faktor dasar bagi setiap aktifitas manusia.Maka daripada itu, untuk melakukan setiap aktifitas seharihari, individu minimal harus mempunyai kemampuan fisik yang selalu mendukung aktifitas tersebut. Dalam menjalankan kehidupan sehari-hari setiap orang tidak akan lepas dari kebugaran jasmani, karena kebugaran jasmani merupakan salah satu faktor yang sangat penting dalam menjalankan kehidupan sehari-hari. Kebugaran jasmani terkait erat dengan keadaan kesehatan seseorang.

Kebugaran jasmani mempunyai fungsi pengemban kesanggupan kerja bagi siapapun, sehingga dapat menyelesaikan tugas pekerjaannya dengan baik dengan tanpa mengalami kelelahan yang berarti. Adapun fungsi dari kebugaran jasmani dapat digolongkan sebagai berikut:

1. Golongan yang dihubungkan dengan pekerjaan

a. Kebugaran jasmani bagi olahragawan dibutuhkan untuk meningkatkan prestasi. 
b. Kebugaran jasmani bagi karyawan dibutuhkan untuk meningkatkan efisien dan produktivitas kerja

c. Kebugaran Jasmani bagi pelajar dan mahasiswa jasmani bagi anak untuk meningkatkan prestasi dan mempertinggi kemampuan hasil belajar.

2. Golongan yang dihubungkan dengan keadaannya

a. Kebugaran jasmani bagi penderita cacat untuk rehabilitasi.

b. Kebugaran jasmani bagi ibu hamil untuk perkembangan bayi dalam kandungan mempersiapkan diri menghadapi saat persalinan.

3. Golongan yang dihubungkan dengan usia

a. Kebugaran jasmani bagi anak untuk menjamin pertumbuhan dan perkembangan yang baik.

b. Kebugaran jasmani bagi orang tua untuk mempertahankan kondisi fisik terhadap serangan penyakit (Syamsudin, 2010).

Manfaat dari kesegaran jasmani meliputi:

a) Fisiologis

Memperkuat sendi-sendi dan ligamen, meningkatkan kemampuan jantung dan paru, memperkuat otottubuh, menurunkan tekanan darah, mengurangi lemak tubuh, mengurangi kadargula, mengurangi resiko terkena penyakit jantung koroner, memperlancar pertukaran gas.

b) Psikologis

Mengendurkan ketegangan mental, suasana hati senang, nyaman dan rasa terhibur.

c) Sosial

Meningkatkan kualitas dan kuantitas persahabatn dengan orang lain serta menghargai lingkungan hidup dan alam sekitar.

d) Budaya atau Kultur

Kebiasaan hidup sehat secara teratur dan terencana, melestarikan nilai-nilai budaya yang berkaitan dengan jenis latihan kesegaran jasmani dan olahraga terpilih (Perdana, 2008).

Kesegaran atau kebugaran jasmani tidak hanya berfungsi dalam olahraga saja tetapi berfungsi secara menyeluruh. Berdasarkan fungsinya kesegaran jasmani bagi pelajar dan mahasiswa meningkatkan kemampuan belajar sedangkan bagi orang dewasa untuk kesehatan seperti mengontrol kondisi fungsiologis tubuh.Kesegaran jasmani dapat ditingkatkan yaitu dengan meningkatkan keseimbangan antara latihan 
olahraga yang dilakukan dengan reaksi organ tubuh dengan latihan fisik secara teratur dan berkesinambungan.

Harvard Step Test merupakan tes untukmenguji tingkat kesegaran atau kebugaran jasmani dengan menggunakan media bangku.Semakin cepat detak jantung kembali normal setelah melakukan tes, semakin baik kebugaran seseorang (Cheevers, 2007).Tes Harvard merupakan salah satu jenis tes untuk meningkatkan kerja jantung untuk mendeteksi atau mendiagnosa penyakit kardiovaskuler juga.Tes ini sangat mudah dilakukan karena tidak membutuhkan biaya yang banyak, sehingga cocok sekali dilakukan oleh orang dewasa, termasuk mahasiswa.

Tujuan dari penelitian adalah untuk mengetahui dan menganalisis seberapa bugar mahasiswa baru semester ganjil tahun akademik 2016/2017 yang masuk ke IKIP Budi Utomo Malang melalui Harvard Step Test.

\section{METODE}

Evaluasi merupakan suatu usaha mengukur hasil dari suatu program dengan cara membandingkan dengan tujuan yg telah ditetapkan secara sistematis, dan bagaimana cara pencapaian tujuan tersebut (Mbulu, 1995). Penelitian evaluasi merupakan suatu prosedur ilmiah yang sistematis yang dilakukan untuk mengukur hasil program atau proyek (efektifitas suatu program) sesuai dengan tujuan yang direncanakan atau tidak, dengan cara mengumpulkan, menganalisisdan mengkaji pelaksaaan program yang dilakukan secara objektif. Kemudian merumuskan dan menentukan kebijakan dengan terlebih dahulu mempertimbangkan nilai-nilai positif dan keuntungan suatu program.Rancangan penelitian ini termasuk penelitian evaluasi yang mana peneliti mengevaluasi hasil tes dan instrumen tes yang sudah dilakukan (model evaluasi Brinkerhoff).

Subjek penelitian ini adalah Mahasiswa Baru Jurusan PJKR Semester Ganjil Tahun Akademik 2016/2017 IKIP Budi Utomo Malang sejumlah 192 mahasiswa, dengan rincian mahasiswa laki-laki sejumlah 180 dan perempuan sejumlah 12 orang.Melalui data yang diperoleh, penelitian dilakukan pada tanggal 14 September 2016 di lapangan kampus A IKIP Budi Utomo.

Instrumen tes yang dilakukan adalah naik turun bangku selama 5 menit dengan bantuan bangku Swedia dengan tinggi $45 \mathrm{~cm}$ dan stopwatch.Observer menentukan umur mahasiswa menggunakan rentang umur 17-19 tahun melalui biodata mahasiswa yang diperoleh 
sebelumnya.Sebelum melakukan tes, observer mencontohkan kepada mahasiswa cara naik turun bangku. Naik turun bangku dilakukan secara bersamaan dengan jumlah 10 mahasiswa tiap sesi dengan 2 observer $(5$ mahasiswa dipantau oleh 1 observer.Mahasiswa dicek pulse rate (denyut nadi) nya pada menit pertama setelah melakukan naik turun bangku menggunakan stopwatch.

Mahasiswa duduk bersandar dan istirahat sambil diukur denyut nadinya.Recoverypulse rate (denyut nadi pulih asal) yang diambil pada menit 1 , menit ke 2, dan menit ke 3 dengan menggunakan palpasi (mengukur denyut nadi menggunakan 3 jari yang ditempelkan di pembuluh darah arteri bagian ulna radialis).Menit ke 2 dan ke 3 sebagai pembanding seberapa besar penurunan pulse rate kembali ke normal (Parmar, 2013).Indeks kebugaran mahasiswa dapat menggunakan rumus; Durasi lama naik turun bangku (detik) x 100/2 $\left(\mathrm{DN}_{1}+\mathrm{DN}_{2}+\mathrm{DN}_{3}\right)$. Berikut Kategori Indeks Kebugaran:

Tabel 1. Kategori Kebugaran

\begin{tabular}{c|c}
\hline Skor & Kategori \\
\hline$<50$ & Kurang sekali \\
\hline $50-64$ & Kurang \\
\hline $65-79$ & Cukup \\
\hline $80-89$ & Baik \\
\hline$>90$ & Sangat Baik \\
\hline \multicolumn{2}{c}{ Sumber: (Parmar, 2013) }
\end{tabular}

Data yang diperolehdimasukkan dan dianalisis menggunakan Microsoft Excel.Data yang telah dianalisis disebarkan kepada mahasiswa sebagai hasil tes kebugaran.

\section{HASIL DAN PEMBAHASAN}

Tes kebugaran yang dilakukan adalah Harvard Step Test. Dari data yang didapatkan bahwa rata-rataumur mahasiswa dan jumlah mahasiswa dengan mahasiswi diperoleh hasil sebagai berikut: 
Tabel 2. Umur dan Jenis Kelamin Mahasiswa Baru PJKR 2016

\begin{tabular}{l|c|c}
\hline Jenis Kelamin & Jumlah & Umur (Mean) \\
\hline Laki-laki & 180 & 18.4 \\
\hline Perempuan & 12 & 18.1 \\
\hline
\end{tabular}

Umur yang diperoleh dari data pendaftaran awal masuk atau registrasi melalui data identitas diri seperti yang tertuang pada tabel 1 . Hasil yang diperoleh mahasiswa dan mahasiswi rata-rata mempunyai tingkat kebugaran pada Harvard Step Test sebagai berikut:

Tabel 3. Rata-rata kebugaran fisik

\begin{tabular}{l|c|c}
\hline Jenis Kelamin & Mean & Kategori \\
\hline Laki-laki & 84 & Baik \\
\hline Perempuan & 84 & Baik \\
\hline
\end{tabular}

Hasil pada tabel 2 tersebut membuktikan bahwa mahasiswa yang masuk menjadi calon mahasiswa IKIP Budi Utomo memiliki tingkat kebugaran yang baik dengan rata-rata 84 . Namun, perlu diingat bahwa tes kebugaran melalui Harvard Step Testbelum mencakup hasil tes dalam bentuk tes kebugaran yang lain.

Data dan hasil tes dari suatu tes kebugaran akan maksimal jika prosedur memperoleh data tes juga benar sesuai teori dan praktek. Dari evaluasi prosedur instrumen tes, diperoleh bahwa observer tidak menggunakanmetronom sebagai alat untuk mengatur ritme naik turun bangku, sehingga mahasiswa satu dengan yang lain berbeda gerakan dalam melakukan tes. Denyut nadi istirahat tidak dihitung dalam penelitian ini yang sebetulnya disini berfungsi sebagai pembanding antara denyut nadi istirahat ke denyut nadi pulih asal setelah melakukan tes.Observer yang bertugas terbatas, sehingga pengukuran denyut nadi tiap mahasiswa terkendala waktu istirahat setelah melakukan tes dan waktu terbuang.

Kebugaran jasmani dapat dibagi menjadi 3 kategori, yaitu kebugaran jasmani yang statis (static), dinamis (dynamic), keterampilan motorik (motoric skills). Kebugaran jasmani statis artinya dikatakan sehat jika seseorang tidak menderita suatu penyakit fisik maupun psikis dan masih tetap produktif bekerja atau istirahat.Kebugaran jasmani dinamis atau fungsional artinya kemampuan tubuh seseorang untuk melakukan tugas atau pekerjaan sehari-hari tanpa kelelahan yang berarti.Sementara itu kebugaran jasmani keterampilan motorik adalah 
kemampuan untuk melakukan gerakan koordinasi yang kompleks (Aida, 2005).

Kebugaran jasmani yang berhubungan dengan unsur kesehatan dan kelompokyang berhubungan dengan unsur keterampilan dan performance. Dalam buku panduan kesehatan olahraga, Remagari (2010) dijelaskan komponen kebugaran jasmani yang berkaitan dengan kesehatan, yaitu:

1. Komposisi Tubuh

a. Persentase (\%) lemak dari berat badan total dan Indeks Masa Tubuh (IMT)

b. Lemak cepat meningkat setelah berumur 30 tahun dan cenderungmenurun setelah berumur 60 tahun.

c. Memberi bentuk tubuh

d. Pengukuran :Skinfold callipers, IMT, IMT = (Berat badan: Tinggi badan ).

e. Obesitas pada anak-anak disebabkan oleh: hipeplasi dan hipertropi sel adiposit serta input berlebihan.

f. Obesitas pada orang dewasa disebabkan oleh: hiperplasi dan hipertropi sel adiposit serta output yang kurang.

2. Kelenturan/fleksibilitas tubuh

a. Luas bidang gerak yang maksimal pada persendian tanpa dipengaruhi oleh suatu paksaan atau tekanan.

b. Dipengaruhi oleh : jenis sendi, struktur tulang, jaringan sekitar sendi, otot, dan ligament

c. Wanita (terutama ibu hamil) lebih lentur dari laki-laki.

d. Anak-anak lebih besar dari orang dewasa.

e. Puncak kelenturan terjadi pada masa pubertas

f. Pentingnya pada setiap gerak tubuh karena meningkatkan efisiensi kerja otot.

g. Dapat mengurangi cidera (orang yang kelenturannya tidak baik cenderung mudah mengalami cidera).

h. Pengukuran: duduk tegak depan (sit and reach test) Flexometer. 
3. Kekuatan Otot

a. Kontraksi maksimal yang dihasilkan otot, merupakan kemampuan untuk membangkitkan tegangan terhadap suatu tahanan.

b. Laki-laki kira-kira 25\% lebih besar dari wanita (Testoteron merupakan anabolik steroid ).

c. Diukur dengan dinamometer.

4. Daya Tahan Jantung Paru

a. a. Kemampuan jantung, paru, dan pembuluh darah untuk berfungsi secaraoptimal pada waktu kerja dalam pengambilan $\mathrm{O} 2$ secara maksimal(VO2 Max)dan menyalurkannya keseluruh tubuh terutama jaringan aktifsehingga dapat digunakan untuk proses metabolism tubuh.

b. Kemampuan otot besar untuk melakukan pekerjaan cukup berat dalam waktu lama secara terus menerus.

c. Merupakan komponen kebugaran jasmani terpenting.

d. Pengukuran: Test lari 2,4 Km ( 12 menit ), Bangku Harvard Test, Ergocycles Test.

\section{Daya Tahan Otot}

a. Merupakan kemampuan untuk kontraksi sub maksimal secara berulang-ulang atau untuk berkontraksi terus menerus dalam suatu waktutertentu.

b. Mengatasi kelelahan.

c. Pengukuran :Push up test, Sit up test.

Selain komponen kebugaran jasmani yang berhubungan dengan kesehatan, diperlukan juga komponen keburagaran jasmani yang berhubungan dengan keterampilan dan performance yang meliputi :

\section{Kekuatan (strength)}

Kekuatan (strength) adalah kemampuan seseorang untuk membangkitkan tegangan (tension) terhadap suatu tahanan (resisten).Kekuatan merupakan hasil kerja otot yang berupa kemampuan untuk mengangkat, menjinjing, menahan, mendorong atau menarik beban. 


\section{Daya Tahan (endurance)}

Daya tahan (endurance) adalah kemampuan tubuh mensuplai oksigen yang diperlukan untuk melakukan suatu kegiatan.Daya tahan otot (muscular endurance) adalah kemampuan otot atau sekelompok otot untuk bertahan melakukan suatu kegiatan dalam waktu yang lama.Daya tahan jantung (cardiovascular endurance) adalah kemampuan seseorang untuk mempertahankan suatu kegiatan yang membutuhkantahanan dalam waktu yang lama.

\section{Kecepatan (speed)}

Kecepatan (speed) adalah kemampuan otot atau sekelompok otot untuk menjawab rangsangan dalam waktu secepat mungkin.Kecepatan gerak adalah kemampuan seseorang untuk melakukan gerak atau serangkaian gerak dalam waktu secepat mungkin.Kecepatan reaksi adalah kemampuan seseorang dalam menjawab suatu rangsang dalam waktu sesingkat mungkin.

\section{Fleksibilitas (flexibility)}

Fleksibilitas (flexibility) mencakup dua hal yang saling berhubungan, yaitu antara kelentukan dan kelenturan.Kelentukan terkait erat dengan keadaan fleksibilitas antara tulang dan persendian, sedangkan kelenturan terkaitdengan keadaan fleksibilitas antara tingkat elastisitas otot, tendo, dan ligamenta.Fleksibilitas (flexibility) mengandung pengertian, yaitu luas gerak satu persendian atau beberapa persendian. Fleksibilitas terbagi menjadi dua, yaitu: fleksibilitas statis dan fleksibilitas dinamis.

\section{Keseimbangan (balance)}

Keseimbangan adalah kemampuan mempertahankan posisi tubuh untuk tidak bergoyang atau roboh, baik dalam posisi diam maupun pada saat melakukan gerakan.

\section{Koordinasi}

Koordinasi adalah kemampuan seseorang untuk menggunakan panca indraseperti penglihatan, dan pendengaran, bersama-sama dengan bagian tubuh tertentu didalam melakukan kegiatan motorik dengan harmonis dan ketetapan tinggi. Koordinasi gerak adalah kemampuan untuk mengatur keserasian gerakan bagian-bagian tubuh.Koordinasi merupakan hasil perpaduan kinerja dari kualitas otot, 
tulang, dan persendian dalam menghasilkan satu gerakan yang efektif dan efisien.

Kebugaran jasmani memiliki tingkat yang berbeda pada setiap individu. Setiap aktivitas fisik dibutuhkan suatu tingkat kebugaran jasmani yang didukung oleh tubuh yang sehat. Menurut Sharkey dalamKusuma (2010), untuk mencapai "quality of life" tersebut ada tiga aspek yang harus dipenuhi, yaitu: mengatur makanan, mengatur istirahat, dan mengatur aktivitas (olahraga).

Olahraga sangat dianjurkan untuk menjaga kebugaran seseorang.Saat berolahraga, tubuh merespon stres yang diberikan.Adaptasi tubuh terhadap aktivitas fisik dapat terjadi pada pembuluh darah disekitar otot yang mengalami vasodilatasi (lebih besar) agar darah lebih banyak dialirkan lebih banyak ke seluruh tubuh. Saat melakukan olahraga atau aktivitas lainnya otot akanmulai berkontraksi dan menghasilkan sisa metabolisme (pembakaran energi), seperti $\mathrm{CO}^{2}$ berupa gas, adenosin dan ion $\mathrm{H}$, yang menyebabkan pembuluh darah kapiler jadi melebar sehingga oksigen yang dibutuhkan bisa sampai ke otot rangka (Nurmila, 2008).Faktor-faktor yang mempengaruhi kebugaran jasmani, yaitu :

\section{Umur}

Kebugaran jasmani tiap individu satu degan yang lainnya sangat berbeda-beda, salah satunya umur. Kapasitas fungsi fisiologi anak-anak meningkat sampai mencapai maksimal pada usia 25-30 tahun, kemudian akan terjadi penurunan kapasitas fungsional dari seluruh tubuh. Namun, jika setiap individu selalu berolahraga, kondisi kebugaran akan terjaga dan penurunan fungsi fisiologis tidak turun secara drastis (dihambat).

\section{Jenis Kelamin}

Kebugaran jasmani anak laki-laki hampir sama dengan anak perempuan pada saat dan sampai pubertas. Namun, setelah pubertas anak-anak laki-laki biasanya mempunyai nilai yang jauh lebih besar. Salah satu faktornya adalah massa otot dan trigliserida (lemak) yang terdapat pada perempuan lebih banyak sebanding dengan produksi hormon perempuan. 


\section{Genetik}

Berpengaruh terhadap kapasitas jantung paru, postur tubuh, obesitas, hemoglobin/sel darah dan serat otot.

\section{Makanan}

Daya tahan yang tinggi bila mengkonsumsi tinggi karbohidrat (60-70\%).Cadangan karbohidrat yang tersisa (glikogen), bisa dipecah lagi menggunakan glukosa jika aktivitas fisik dilakukan.Diet tinggi protein terutama untuk memperbesar otot dan untuk olahraga yang memerlukan kekuatan otot yang besar.

\section{Pola Hidup Sehat}

Kadar $\mathrm{CO}$ yang terhisap akan mengurangi nilai $\mathrm{VO}^{2}$ maks dan daya serap oksigen ked lam alveoli, yang berpengaruh terhadap daya tahan paru-paru. Selain itu menurut penelitian Perkins, nikotin yang terkandung di dalam rokok dapat memperbesar pengeluaran energi dan mengurangi nafsu makan (Kusuma, 2009).

Harvard Step Test merupakan tes ketahanan (endurance) terhadap kinerja jantung dan paru.Tes ini dapat menghitung kemampuan daya tahan seseorang untuk melakukan aktivitas fisik secara terus-menerus dalam jangka waktu yang lama tanpa lelah. Subjek melakukan naik dan turun pada bangku setinggi $45 \mathrm{~cm}$. Subjek melakukan naik turun bangku selama 5 menit atau dengan kata lain sampai subjek kelelahan dan tidak melanjutkan tes. Kelelahan adalah ketika saat subjek tidak mampu lagi mempertahankan langkahnya dalam 15 detik.Subjek didudukkan dan merupakan akhir dari tes, dan denyut nadinya kemudian dihitung dalam 1, 2 dan 3 menit (Nurmila, 2008).

\section{KESIMPULAN DAN SARAN}

Dari hasil dan pembahasan yang telah disampaikan, dapat disimpulkan bahwa mahasiswa yang di tes kebugaran jasmaninya melalui Harvard Step Testdengan cara melakukan tes tersebut selama 5 menit dengan bantuan bangku Swedia dengan tinggi $45 \mathrm{~cm}$ dan stopwatchmendapatkan rata-rata dengan kategori baik. Hasilnya, lakilaki (180) dan perempuan (12) mahasiswa IKIP Budi Utomo memiliki tingkat kebugaran yang baik dengan rata-rata 84.Tes yang dilakukan belum mencakup seluruh tes kebugaran jasmani yang harus dilakukan mahasiswa, namun peneliti mendapat gambaran secara garis besar 
kondisi kebugaran mahasiswa baru yang masuk Jurusan Pedidikan Jasmani Kesehatan dan Rekreasi.

Unsur-unsur kebugaran jasmani dapat dijadikan sebagai pedoman untuk menentukan seseorang bugar atau tidak, yaitu: 1) daya tahan kardiorespirasi (endurance), 2) daya tahan otot, 3) kekuatan otot (strength), 4) kelentukan (flexibility), 5) komposisi tubuh, 6) kecepatan (speed), 7) kecepatan reaksi (speed reaction), 8) daya ledak (power), 9) kelincahan (agility), 10) keseimbangan (balance), 11) ketepatan (accuracy), 12) koordinasi (coordination). Faktor-faktor yang mempengaruhi kebugaran jasmani adalah umur, jenis kelamin, genetik, makanan dan pola hidup sehat.

Saran bagi observer, jika menggunakan instrumen tes kebugaran harus menggunakan protokol yang tepat sehingga hasil dari variabel yang di tes bisa terhitung valid.Jumlah observer harus bisa disesuaikan dengan jumlah mahasiswa baru sehingga pada saat memberikan tes tidak terlalu berat mengobservasinya.

\section{DAFTAR RUJUKAN}

Aida, Y. 2005. Fisiologi Hewan. Fakultas Biologi UAJY, Yogyakarta. Cheevers, A \& Pettersen, C. 2007.Harvard Step Test. Amsterdam Institute of Allied Health EducationEuropean School of Physiotherapy.

Kusuma, A. 2009.Faktor-Faktor yang Mempengaruhi Kebugaran Jasmani.(http://afand.cybermq.comdiakses 10 Desember 2016). Mbulu, J. 1995. Evaluasi Program Konsep Dasar, Pendekatan Model, dan Prosedur Pelaksanaan. Malang: Departemen Pendidikan dan Kebudayaan Institut Keguruan dan Ilmu Pendidikan Malang Proyek Operasi dan Perawatan Fasilitas. Nurmila, W. 2008.Laporan Fisiologi

Harvard.(http://odhemila.blogspot.comdiakses 10 Desember 2016).

Parmar, D \& Modh, N. 2013. "Study of Physical Fitness Index Using Modified Harvard Step Test in Relation with Gender in Physiotherapy Students". International Journal of Science and Research (IJSR): Vol: 4, Issue: 7.

Perdana, 2008.Kebugaran Jasmani.

(http://perdhana.wordpress.comdiakses 10 Desember2016). 
Remagari. 2010. Tes dan Pengukuran Kebugaran Jasmani.

(http://www.remagari.co.cc. diakses10 Desember 2016).

Syamsudin, E. 2010.Apa

ItuKebugaran.(http://flawlessimagine.blogspot.com. 22 Desember 2016. 